AVANT, wol. IX, nr 3/2018

ISSN: 2082-6710 avant.edu.pl/en

DOI: 10.26913/avant.2018.03.07

omäerses

\title{
Afordancje w (i poza) HCI \\ Recenzja książki Affordances and Design
}

Autor: Victor Kaptelinin

Wydawca: The Interaction Design Foundation

Rok wydania: 2014

Liczba stron: 116

\author{
Witold Wachowski \\ Instytut Filozofii \\ Uniwersytet Warszawski \\ witoldwachowski@gmail.com
}

Otrzymano 23 sierpnia 2018, zaakceptowano 12 września 2018, opublikowano zimią 2018/2019.
VICTOR KAPTELININ

AFFORDANCES AND

DESIGN

\begin{abstract}
Abstrakt
Artykuł stanowi przegląd recenzyjny książki Victora Kaptelinina Affordances and Design, w której omówiono koncepcję afordancji w interakcji człowiek-komputer (ang. humancomputer interaction, HCI). Adresowany do polskiego czytelnika, umożliwia mu zorientowanie się w podstawowych relacjach i różnicach między filozofią i psychologią ekologiczną a teoriami projektowania, głównie na przykładzie pionierskiej propozycji Jamesa Gibsona i (ewoluującej) koncepcji Donalda Normana, w pewnym odniesieniu do szerszego kontekstu.
\end{abstract}

Słowa kluczowe: poznanie; afordancja; psychologia ekologiczna; dizajn; HCI. 


\section{Wprowadzenie}

Przede wszystkim powinienem wyjaśnić, jaki jest powód lub powody publikowania polskojęzycznej recenzji książki sprzed kilku lat. A powody zasadniczo są dwa.

Niebawem ukaże się polski przekład The Design of Everyday Things ${ }^{1}$ (pierwsza wersja z 1988 nosiła tytuł The Psychology of Everyday Things), najbardziej poczytnej książki Donalda Normana, uznanego kognitywisty i teoretyka dizajnu, co po niedawnej publikacji przekładu Emotional Design ${ }^{2}$ tegoż autora można uznać za nadrabianie jego wieloletniej nieobecności na polskim rynku wydawniczym. Tymczasem całokształt publikacji Normana - od książek, w których chętnie używa popularyzatorskiego języka, po artykuły w specjalistycznych czasopismach - jest zapisem dynamicznej i ewoluującej aktywności naukowej. Już pomiędzy dwiema wymienionymi wyżej pracami jest niemało różnic, dlatego warto, czy wręcz należy, zobaczyć tę twórczość w kontekście ewolucji zarówno jego dorobku, jak i dziedziny badań nad szeroko rozumianym dizajnem. I taki jest pierwszy powód tej recenzji.

Drugi powód dotyczy niezwykłej i raczej niepożądanej sytuacji związanej z różnymi kierunkami „kariery” koncepcji afordancji. W opublikowanym w 2015 roku komentarzu do numeru specjalnego czasopisma Articial Intelligence for Engineering Design, Analysis and Manufacturing Norman pozwolił sobie nieco ponarzekać na utrzymujący się brak interakcji między filozofią i psychologią ekologiczną a rozległą i zróżnicowaną dziedziną projektowania. Przedstawiciele tej pierwszej wydają się nieświadomi wykorzystania koncepcji afordancji w drugiej, ale też projektanci nie są świadomi zastosowania jej w inżynierii i tak dalej. Dowodzi to utrzymywania się nieprzenikalnych murów między dyscyplinami, wbrew interdyscyplinarnym trendom czy też deklaracjom. Norman przytacza przykłady opracowań historii i stanu badań nad afordancjami (zob. Chemero, 2003; Dotov, de Wit, Nie, 2012), w zamierzeniu kompleksowych i wyważonych, dokonywanych przez teoretyków psychologii ekologicznej, które jednak ewidentnie ignorują prace spoza ich dziedziny. Można to uzupełnić jeszcze bardziej chyba zdumiewającym spostrzeżeniem, że w konsekwencji filozofia i psychologia ekologiczna podejmują sam wątek dizajnu w oderwaniu od dorobku prac teoretycznych na tym polu (zob. np. Rietveld, Kiverstein, 2014). Z tych właśnie względów warto przyjrzeć się temu, jak postrzegany jest dorobek ojca koncepcji afordancji i psychologii ekologicznej, Jamesa Gibsona, w kontekście dizajnu, z naciskiem na badania nad interakcjami człowiek-komputer (HCI, human computer-interaction).

\footnotetext{
${ }^{1}$ D. Norman. Dizajn na co dzień. Przeł. D. Malina. Kraków: Wydawnictwo Karakter [zapowiedź wydawnicza].

${ }^{2}$ D. Norman. (2015). Wzornictwo i emocje. Dlaczego kochamy lub nienawidzimy rzeczy powszednie. Przeł. D. Skalska-Stefańska. Warszawa: Wydawnictwo Arkady.
} 


\section{Ogólna charakterystyka książki}

Autorem Affordances and Design jest Victor Kaptelinin, profesor Wydziału Informatyki szwedzkiego Uniwersytetu w Umeå, zajmujący się problematyką projektowania interakcji, teorią działania i edukacyjnym wykorzystaniem technologii informacyjnych ${ }^{3}$. Warto również zwrócić uwagę na wydawnictwo: Interaction Design Foundation jest organizacją edukacyjną typu non-profit, udostępniającą bezpłatnie materiały edukacyjne $\mathrm{z}$ dziedziny projektowania interakcji, w tym profesjonalne podręczniki akademickie, jak i recenzowaną encyklopedię 4 .

Niewielkie rozmiarem dziełko Kaptelinina stanowi stosunkowo rozległe tematycznie i wyczerpujące opracowanie zastosowania koncepcji afordancji w dziedzinie HCI, wraz ze źródłami tej koncepcji i towarzyszącymi jej kontrowersjami oraz z szerszym kontekstem dizajnu na dalszym planie. Składa się ono z sześciu rozdziałów. Pierwszy, o charakterze wprowadzenia („Introduction: Why affordances?”), pokazuje ogólną wagę i różnorodność zastosowań tej koncepcji. Drugi (,Theoretical roots”) poświęcony jest propozycji teoretycznej Gibsona jako twórcy psychologii ekologicznej, jak również wybranym analizom afordancji w późniejszej fazie rozwoju tej dziedziny. W rozdziale trzecim („Affordances in HCI research: An overview”) przedstawiono wybór najważniejszych analiz afordancji w dziedzinie HCI. Jak potwierdza autor, jego przegląd jest nieuchronnie selektywny i niekompletny z uwagi na ogromną ilość literatury HCI wykorzystującej pojęcie afordancji, co uniemożliwia objęcie wszystkich istotnych prac (na przykład wyszukiwanie zestawienia terminów „HCI” i ,afordancja” w bibliotece cyfrowej Association for Computing Machinery jeszcze z czerwca 2013 dało 1790 trafień). Natomiast w czwartym rozdziale („Key issues of debate”) Kaptelinin omawia największe kontrowersje pojawiające się w dyskusjach nad tematem, siłą rzeczy w powiązaniu z treścią poprzedniego rozdziału. Podsumowujący rozdział piąty („Conclusion: Reflections on the present and future of affordances as an HCI concept”) dostarcza refleksji nad teraźniejszością i przyszłością koncepcji afordancji w HCI. I wreszcie ostatni, szósty rozdział pracy („Where to learn more”) stanowi krótki wykaz najważniejszych publikacji dotyczących afordancji i psychologii ekologicznej w ogóle, jak również afordancji w HCI.

W dalszym toku swojego omówienia książki Kaptelinina chciałbym skoncentrować się na czterech wątkach w niej obecnych, między innymi z uwagi na ich potencjał w kontekście badań kognitywistycznych. Pierwszy z tych wątków to rola Gibsona w konceptualizacji afordancji. Drugi to udział i ewolucja koncepcji Normana. Trzeci stanowi omówienie pionierskich analiz Williama Gavera. Zaś czwarty, uzupełniający wątek, rozwijany też w kontekście wymienionych wcześniej, to problem jednoznacznego odróżnienia afordancji od innych fenomenów obecnych w projektowaniu.

\footnotetext{
${ }^{3}$ Zob. http://www.informatik.umu.se/english/about-the-department/staff/victor-kaptelinin/ (dostęp 14.03.2018).

${ }^{4}$ Zob. https://www.interaction-design.org (dostęp 14.03.2018).
} 


\section{James J. Gibson}

Jaki jest sekret projektowania artefaktów intuicyjnych czy oczywistych w obsłudze? Przywołane przez Kaptelinina pierwsze z brzegu przykłady - jak klamki, składane noże, ale też urządzenie do głosowania w wyborach - zdają się pokazywać, że nie chodzi tutaj o racjonalność czy logikę tkwiącą w projekcie obiektu, któremu przed użyciem ledwo się przyglądamy. Chodzi raczej o samo patrzenie, o związek z niekontrolowaną sferą percepcji. Intuicyjny (w obsłudze) artefakt umożliwiać ma nam niejako be z p ośrednie, a przy tym poprawne, oczekiwane dostrzeżenie tego, co możemy (właściwego) zrobić z tą rzeczą. A właśnie to $\mathrm{w}$ jakiś sposób bezpośrednie postrzeganie możliwości działania zasadniczo jest tym, jak pisze autor, o co chodzi w koncepcji afordancji. Jej autorem jest Gibson, amerykański psycholog, który zaproponował ją dla optymalnego określenia tego, co otoczenie „oferuje zwierzęciu, co mu zapewnia lub w co wyposaża, dla jego dobra lub szkody" (Gibson, 1979, s. 127). Używając prostego przykładu z książki, można powiedzieć, że ogrodzenie do określonej wysokości służy koniom afordancją ,przeskakiwalności” (czy „czegoś-możliwego-do-przeskoczenia”), ale już nie owcom, te bowiem poradzą sobie dopiero $\mathrm{z}$ odpowiednio niższą przeszkodą.

Dla Kaptelinina istotne jest, jak formowała się ta koncepcja zanim za sprawą Normana (1988) pojawiła się w dziedzinie projektowania, w tym również w HCI. A formowała się nie od lat 70., jak za innymi wskazuje autor książki, lecz już od lat 50., by zaowocować gotowym terminem (neologizmem) prawdopodobnie w 1966 roku (Gibson, 1966, s. 285; zob. też Costall, 2012 s. 296-298). Kluczową dla teorii Gibsona ideą jest wzajemność czy też komplementarność podmiotu i środowiska - przy czym powinienem tutaj wiernie za Gibsonem użyć nie słowa ,podmiot”, lecz „zwierzę”, bo też i konsekwentnie teoria ta zakorzeniona jest w biologii. W każdym razie: podmiot (człowiek czy inne zwierzę) wraz z jego środowiskiem tworzą jeden system, są elementami jednej struktury. Dane cechy jakiegoś środowiska są istotne dla takiego, a nie innego zwierzęcia $\mathrm{i}$ - w drugą stronę morfologia i umiejętności, którymi dysponuje zwierzę, wykształciły się w powiązaniu z warunkami i możliwościami jego środowiska.

Autor Affordances and Design wskazuje na cztery ważne tezy Gibsona. Po pierwsze, środowiska danych zwierząt są ustrukturyzowane, czyli zorganizowane w określone konfiguracje substancji i powierzchni, dynamiczne i zmienne obiekty, układy i zdarzenia. Zgodnie z drugą tezą owe struktury są znaczące dla zwierząt; mogą oznaczać narzędzia, schronienia, ale też przeszkody. Na mocy trzeciej tezy owe struktury w pewien sposób odzwierciedlają się w zmiennej strukturze otaczającego światła, odbijającego się od obiektów i docierającego do zwierzęcia. A po czwarte, przez wykrywanie niezmienników w owych strukturach świetlnych zwierzęta mogą bezpośrednio otrzymywać potrzebne dla siebie informacje i nie muszą przy tym korzystać z umysłowych reprezentacji otaczających obiektów. Są to informacje o afordancjach, czyli możliwościach działania. Warto przy tym nadmienić, że Gibson nie był skoncentrowany na afordancjach jako takich i traktował tę koncepcję dość instrumentalnie. Ważny był dla niego nie sposób ich istnienia, tylko opisanie za ich pomocą percepcyjnej dostępności informacji w otaczającym świetle. 
Kaptelinin zwraca uwagę na to, że Gibsonowska koncepcja afordancji zdradza pewne podobieństwa $\mathrm{z}$ ujęciami proponowanymi w ramach psychologii postaci, co zresztą przyznawał sam Gibson, wskazując na wpływy Kurta Koffki i Kurta Lewina. Jednocześnie jednak autor The Ecological Approach to Visual Perception wskazuje na istotną różnicę, o której stanowi stałość afordancji: nie zmienia się ona w zależności od zmian potrzeb obserwatora, nie stanowi jego projekcji na rzeczy w sytuacji zapotrzebowania na coś.

\section{Donald Norman}

W omawianej książce Gibson zostaje nieuchronnie skonfrontowany z Normanem. Przy czym jej autor przywołuje między innymi analizy dokonane przez Joannę McGrenere i Wayne'a Ho (2000). W ich ujęciu afordancje Gibsonowskie mają charakter binarny (są lub ich nie ma); zdają się też być niezależne od kultury oraz indywidualnego doświadczenia, wiedzy i zdolności do postrzegania. Natomiast afordancje Normanowskie oznaczają postrzegane własności, które mogą, ale nie muszą faktycznie istnieć; są zależne od czynników kulturowych i indywidualnych; mogą czynić działanie trudnym lub łatwym; ponadto Norman nie eliminuje reprezentacji z procesu poznawczego. Za najbardziej zasadniczą różnicę w definiowaniu afordancji uważa się tutaj to, że dla Gibsona afordancja jest możliwością działania, podczas gdy dla Normana jest równocześnie taką możliwością oraz sposobem, w jaki jest ona przekazywana lub uwidaczniana podmiotowi. Warto też może spojrzeć na te różnice w kontekście celów przyświecających tym badaczom. Podczas gdy autor The Ecological Approach to Visual Perception koncentrował się na tym, jak postrzegamy otoczenie, autor The Psychology of Everyday Things skupił uwagę na manipulowaniu i projektowaniu elementów tego otoczenia, aby uzdatnić postrzeganie jego użyteczności. Afordancje dla tego ostatniego to ,postrzegane lub faktyczne właściwości danej rzeczy, zwłaszcza te podstawowe właściwości, które decydują o tym, jak owa rzecz mogłaby zostać użyta" (Norman, 1988, s. 9). Pamiętajmy tutaj, że w HCI podmiot ma do czynienia również z interfejsem użytkownika, czyli przestrzenią interakcji z urządzeniem, która wykorzystuje swoisty wirtualny „świat postrzegany”, jak w przypadku obrazu generowanego na monitorze komputera.

Koncepcja Normana zaprezentowana w jego książce z 1988 nie spotkała się jednak z pełnym zrozumieniem, więcej: spowodowała zamieszanie i opaczne rozumienie w środowisku projektantów. W efekcie doprowadziło to Normana (1999) do rozróżnienia między afordancjami realnymi a (tylko) postrzegany mi, których działanie wydaje się sprowadzać do informacji percepcyjnej, ale bez możliwości działania. Takimi postrzeganymi afordancjami służą chociażby różnego rodzaju graficzne elementy typu „przyciski” na ekranie komputera, oferujące klikanie, przesuwanie itd.

W książce z 1988 Norman wskazał na trzy główne wymiary umożliwiające zrozumienie działania nowego urządzenia: modele konceptualne, ograniczenia (constraints) oraz afordancje. Autor podkreśla wagę modelu konceptualnego, który w społeczności projektantów spotkał się z deklaratywną akceptacją, lecz zbyt małym wdrożeniem praktycznym. Z kolei 
waga ograniczeń została jego zdaniem raczej zignorowana. Dużym zaskoczeniem dla Normana było powszechne przyjęcie koncepcji afordancji w tej społeczności, jednak z niedostatecznym zrozumieniem. Autor obarcza za to winą siebie, jako że skupiał się na afordancjach postrzeganych, do których często sprowadzano jego teorię (Norman, 1999, s. 38). Aby wyklarować rozumienie realnych afordancji, badacz dokonuje rozróżnienia między ograniczeniami fizycznymi, logicznymi i kulturowymi, ściśle wiążąc owe afordancje z pierwszym typem ograniczeń.

Kaptelinin zwraca uwagę na analizę Normanowskiego tak zwanego modelu działania dokonaną przez H. Rexa Hartsona (2003) w kontekście typów afordancji, do których należą: afordancje poznawcze (wspomagają użytkowników w działaniach poznawczych; afordancje postrzegane), fizyczne (wspierają w aktywności fizycznej; afordancje realne), sensoryczne (ważna rola w projektowaniu, wsparcie dla użytkowników w aktywności sensorycznej) oraz funkcjonalne (wiążą zastosowanie (usage) z przydatnością (usefulness)). Owe typy afordancji Hartson odnosi do wspomnianego Normanowskiego modelu działania, w którym afordancje poznawcze i sensoryczne wiążą się z przejściem od intencji do działania przez planowanie sekwencji działań, afordancje fizyczne i sensoryczne dotyczą wykonania sekwencji działań, te ostatnie związane są z postrzeganiem aktualnego stanu rzeczy, zaś poznawcze przydają się podczas interpretowania tego, co postrzegane.

W jeszcze późniejszym okresie badań Norman wyraża szczególne zainteresowanie signifiers, ,znacznikami” (2008, 2011, 2013), które rozumie jako wszelkie postrzegane wskazówki właściwego zachowania dla danej osoby. Podczas gdy afordancje określają, jakie działania są możliwe, signifiers precyzują owe możliwości, stanowią rodzaj wyczuwalnych sygnałów tego, co można zrobić. Z tego powodu, według Normana, projektanci powinni do tych ostatnich przykładać dużo większą wagę.

Jak jednak zauważa Kaptelinin, rozdzielenie afordancji i signifiers nie wydaje się takie oczywiste u Normana. W The Design of Everyday Things z jednej strony dokonuje tego rozdzielenia, z drugiej strony - w innych miejscach książki - określa signifiers jako komponenty afordancji, czy wręcz pewne przypadki signifiers nazywa afordancjami postrzeganymi.

Próbując podsumować to, jak ewoluowało ujęcie afordancji tego najbardziej wpływowego ich teoretyka w dziedzinie HCI i ogólnie dizajnu, można za autorem Affordances and Design wyróżnić trzy zasadnicze etapy: (1) 1988: Wprowadzenie pojęcia do dziedziny dizajnu. „Afordancje” oznaczają tu jednocześnie możliwości działania dostarczane czy prezentowane podmiotowi oraz ich percepcję. (2) 1999: Norman odróżnia afordancje realne od postrzeganych. (3) 2008, 2011, 2013: Badacz wydaje się całkowicie rozdzielać afordancje od informacji o nich (signifiers), co nie wychodzi mu do końca konsekwentnie.

\section{William Gaver}

Kaptelinin wskazuje również na innych oryginalnych badaczy. Między innymi docenia pionierskie analizy afordancji w dziedzinie HCI wykonane przez Gavera, szczególnie począwszy od nadal chyba niedocenionego artykułu „Technology affordances” z roku 1991. 
Autor ten zgłębił i opisał możliwe związki między afordancjami a informacją percepcyjną. Na tej podstawie wyróżnił: afordancje dostr ze galne czy też jawne (towarzyszy im informacja percepcyjna), fa ł s z y we (mimo informacji percepcyjnej brakuje możliwości działania; por. Normanowskie afordancje postrzegane), uk ry te (możliwości działania mimo braku percepcyjnej informacji) oraz sytuację poprawnego odrzucenia możliwości działania (przy braku afordancji i percepcyjnej informacji).

Kolejną zasługą Gavera jest pokazanie wagi konfiguracji własności w obiekcie. Afordancje mogą występować jako zło ż o n e: zestawione w sekwencjach lub też zagnieżdżone w bardziej skomplikowanych strukturach. Dobrze to ilustruje chociażby prosty przykład drzwi: w ich afordancji otwierania czy przechodzenia zagnieżdżona jest afordancja naciskania klamki, a następnie afordancja pociągania lub popychania drzwi przed siebie.

Ten sam badacz podkreśla, że informacje o afordancjach bynajmniej nie ograniczają się do wizualnych, lecz obejmują też inne modalności, jak słuch czy dotyk, oraz ich kombinacje (np. 1986). Zwraca także uwagę na postrzeganie i wykorzystanie przestrzeni medialnych, jak również na afordancje dla interakcji społecznych, które powinny być niezwykle ważne dla projektantów o niektórych specjalizacjach $(1992,1996)$.

\section{Afordancje, nie-afordancje, jakby afordancje...}

Liczba i zróżnicowanie zastosowań koncepcji afordancji w HCI i innych obszarach projektowania wiąże się z szeregiem trudności i nieoczywistości w identyfikowaniu tego pojęcia. Pokazuje to opisana już w części tekstu poświęconej Normanowi sytuacja z afordancjami realnymi i postrzeganymi oraz signifiers. Warto tu przywołać jeszcze dwa zjawiska, mianowicie feedforward oraz skeumorfizm.

Feedforward określa się jako informację dostarczaną użytkownikowi przed wykonaniem przezeń działania - tak jak można określić feedback jako informację dostarczaną użytkownikowi po działaniu. W przytaczanej przez Kaptelinina pracy autorstwa Jo Vermeulena i innych (2013) dokonuje się porównania feedforward $\mathrm{z}$ afordancjami postrzeganymi. Te ostatnie pozwalają ujawnić się afordancjom fizycznym, które wskazują użytkownikowi istnienie jakiegoś możliwego do zrealizowania działania fizycznego oraz to, jak należy je zrealizować. Natomiast feedforward, zdaniem tych autorów, ujawnia funkcjonalną afordancję, dostarczającą informację o tym, co się zdarzy, kiedy użytkownik wykona dane działanie.

Z kolei skeumorfizm odnosi się do swoistego imitowania postrzeganych właściwości jednego obiektu w drugim. Przykładem mogą być plastikowe opakowania imitujące drewno czy też efekt trójwymiarowości graficznych elementów na monitorze. Bardziej czy mniej realistyczne wrażenia wywoływane przez obiekty skeumorficzne modyfikują w jakiś sposób nasze działania z ich użyciem czy też nasz stosunek do tych działań (choćby na poziomie nastroju). Ostatnio jednak skeumorfizm w HCI odchodzi do lamusa, czy to z powodu wiązania go przez jego krytyków z nostalgią czasów ery komputeryzacji obcą młodszym pokoleniom, czy to z racji uznania zapośredniczenia w cechach jakichś fizycznych obiektów za przeszkodę w efektywniejszym projektowaniu. 


\section{Podsumowanie}

Książka Kaptelinina, przybliżona przeze mnie w zakresie wybranych wątków, obrazuje dynamikę konceptualizowania afordancji, jak również wdrażania tych koncepcji, przy różnych ich niedostatkach oraz w kontekście zbliżonych fenomenów i alternatywnych teorii. Autor zadaje pytanie o przyszłość koncepcji afordancji w HCI i ocenia sytuację następująco: „główne wyzwania związane z zastosowaniem nowych konceptualizacji afordancji (lub koncepcji powiązanych z nimi) w HCI wiążą się z wyklarowaniem znaczenia tego pojęcia oraz wyznaczeniem mu miejsca $w$ ramach określonego programu badań, jak również uczynienie go użytecznym i dostosowanym do projektantów i innych praktyków HCI" (Kaptelinin, 2014, s. 91).

Natomiast moim - dodatkowym - zadaniem tutaj było uświadomienie czytelnikom słabiej obeznanym z tematem, a sięgającym po przekłady prac Normana, jakie są związki między psychologią ekologiczną a dziedziną dizajnu (nie tylko w HCI) oraz jak zmieniała się koncepcja afordancji najbardziej wpływowego teoretyka projektowania w reakcji na nieporozumienia, a także jakie są teoretyczne alternatywy.

\section{Bibliografia}

Chemero, A. (2003). An outline of a theory of affordances. Ecological Psychology, 15(2), 181-195.

Costall, A. (2012). Afordancje kanoniczne w kontekście. Avant, 3(2), 296-304.

Dotov, D. G., de Wit, M. M., Nie, L. (2012). Understanding affordances: history and contemporary development of Gibson's central concept. Avant, 3(2), 28-39.

Gaver, W. W. (1986). Auditory Icons: Using Sound in Computer Interfaces. Human-Computer Interaction, 2(2), 167-177.

Gaver, W. W. (1991): Technology Affordances. W: S. P. Robertson, G. M. Olson, and J. S. Olson (red.), Proceedings of the ACM CHI 91 Human Factors in Computing Systems Conference (s. 79-84). New Orleans, LA: ACM Press.

Gaver, W. W. (1992). The Affordances of Media Spaces for Collaboration. W: Proceedings of the 1992 ACM conference on Computer-supported cooperative work (s. 17-24). Toronto, ON: ACM Press.

Gaver, W. W. (1996). Affordances for interaction: The social is material for design. Ecological Psychology, 8(2), 111-129.

Gibson, J. J. (1966). The senses considered as perceptual systems. Boston, MA: Houghton-Mifflin.

Gibson, J. J. (1979). The Ecological Approach to Visual Perception. New York, NY: Psychology Press.

Hartson, H. R. (2003). Cognitive, physical, sensory, and functional affordances in interaction design. Behaviour and Information Technology, 22(5), 315-338.

Kaptelinin, V. (2014). Affordances and Design. The Interaction Design Foundation. 
McGrenere, J., Ho, W. (2000). Affordances: Clarifying and Evolving a Concept. W: The Proceedings of Graphics Interface 2000 (s. 179-186). Montreal, QC: Canadian Human-Computer Communications Society.

Norman, D. (1988). The Psychology of Everyday Things. New York, NY: Basic Books.

Norman, D. (1999). Affordance, conventions, and design. Interactions, 6(3), 38-43.

Norman, D. (2008). Signifiers, not affordances. Interactions, 15(6), 18-19.

Norman, D. (2011). Living with Complexity. Cambridge, MA: MIT Press.

Norman, D. (2013). The Design of Everyday Things. New York, NY: Basic Books. Polski przekład: Dizajn na co dzień. Przeł. D. Malina. Kraków, Polska : Wydawnictwo Karakter [zapowiedź wydawnicza].

Norman, D. (2015). Wzornictwo i emocje. Dlaczego kochamy lub nienawidzimy rzeczy powszednie. Przeł. D. Skalska-Stefańska. Warszawa, Polska: Wydawnictwo Arkady.

Rietveld, E., Kiverstein, J. (2014). A rich landscape of affordances. Ecological Psychology, 26(4), $325-352$.

Vermeulen, J., Luyten, K., Hoven, E. van den, Coninx, K. (2013). Crossing the bridge over Norman's gulf of execution: Revealing feedforward's true identity. W: Proceedings of HCI 2013 (s. 1931-1940). Paris, Francja: Springer.

\title{
Źródla internetowe
}

Informacja o autorze: http://www.informatik.umu.se/english/about-the-department/staff/victor-kaptelinin/(dostęp 14.03.2018).

Informacja o wydawnictwie: https://www.interaction-design.org (dostęp 14.03.2018).

\section{Affordances in (and outside) HCI: A book review}

\begin{abstract}
This paper is a review of the book by Victor Kaptelinin Affordances and Design, devoted to the concept of affordances in HCI. It discusses, among others, basic relations and differences between ecological psychology (including a branch of philosophy of cognition) and design studies.
\end{abstract}

Keywords: cognition; affordances; ecological psychology; design; HCI. 